受賞者総説

海洋微生物の分子生態学に関する研究

(平成 17 年度水産学奨励賞受賞)

浦 川秀 敏*

東京大学海洋研究所先端海洋システム研究センター

Molecular ecology of marine microorganisms

\title{
HIDETOSHI URAKAWA
}

Center for Advanced Marine Research, Ocean Research Institute,

The University of Tokyo, Nakano, Tokyo 164-8639, Japan

環境中の微生物群集を把握するためには, その群集組 成や多様性, 現存量, そしてそれらのもつ機能を明らか にする必要がある。従来, 海洋微生物学の研究は, 培養 した菌株を扱うことが中心であったが，1990年代に入 り, 海洋微生物学に積極的に分子生物学的研究手法が導 入され, 海洋微生物に関わる多くの新知見が蓄積される ようになった。1)

\section{1. 低温環境に生息するビブリオ科細菌の研究}

ビブリオ科細菌は海洋の常在菌で海水, 汽水環境から 容易に分離することができる。この細菌のグループは, ヒトや海洋生物の病原菌を多数含んでいる。そのため, ビブリオ科細菌の簡易迅速な同定法の確立には，多くの 研究者や技術者が注目してきた。またそれに伴い，さま ざまな技術が開発されてきた。

本研究では, ビブリオ科細菌の同定のために，16S rRNA 遺伝子の制限酵素断片長多型解析 (restriction fragment length polymorphism [RFLP] analysis) に注 目した。まず標準菌株の制限酵素切断パターンのデータ ベースを作成する目的で, 35 種 49 菌株の切断パターン について分析を行った。5 種の 4 塩基認識制限酵素の切 断パターンから，供試菌株を 25 の遺伝子型に分類する ことができた。2）特に，従来の表現形質による分類では 区別することが困難なビブリオ科の 2 属, ビブリオ属 とフォトバクテリウム属を HhaI の切断パターンで簡易 迅速に判別できることが示された。3)さらにこの結果か ら派生し，これまでビブリオ属細菌であると考えられて いたVibrio iliopiscarius が，実際はPhotobacterium に属 することを証明し, Photobacterium iliopiscarium として
再分類を行なった。 ${ }^{4}$

次に, 得られた情報をもとにして, 特に低温環境に着 目し, 海洋でのビブリオ科細菌の分布や遺伝的特性を明 らかにするために研究を続けた。白鳳丸や淡青丸といっ た研究船を用いて太平洋西部海域や相模湾, 駿河湾周辺 海域の深層水，そして大桘湾の沿岸から 60 株のビブリ オ科細菌を採集した。 4 種の 4 塩基認識制限酵素の切断 パターンから，供試菌株を 4 つのグループ（Vibrio logei, Vibrio splendidus, Vibrio marinus, Photobacterium), 15 の遺伝子型に分類することができた。特に注目に值 したのは, すべて外洋から分離された菌株で構成された V. marinus のグループである。V. marinus は, 1964 年 に初めて報告されて以来, 5) 好冷菌のモデルとして, 特 に低温酵素に関する研究に多く用いられてきた。6) それ にも関わらず, 1 種 1 株がアメリカンタイプカルチャー コレクション $(\mathrm{ATCC})$ に登録されているのみで, その 生態に関する情報は限られていた。V.marinus グルー プに属した菌株は, 水深 $500 \mathrm{~m}$ 以深からの久分離され たことから, 浅海域からも深海からも分離された Vibrio splendidus グループの菌と異なり, 深海域に限っ て生息している菌であることが示された。また利用でき る糖の種類が少なく, $25^{\circ} \mathrm{C}$ 以上では増殖しないなど, 有機物に乏しく低温環境が保たれている深海に適応して いる性質も備えていた。7) 16S rRNA 遺伝子を用いた系 統解析などの結果から，V. marinus はビブリオ科に含 めるよりも，新属に移したほうが良いと判断し，

Moritella marina として新属, 新種提案を行なった。8)

それぞれの遺伝子型に属した菌株の分離場所について 照合したところ, 同じ低温環境でも, 日本の高緯度地域

* Tel. : 81-3-5351-6854. Fax : 81-3-5351-6854. Email : urakawa@ori.u-tokyo.ac.jp 
のように季節的に海水温が低温になる環境に生息するビ ブリオ科細菌と, 恒常的に低温が維持されている外洋深 層水のような環境に生息する種間で，遺伝的に区別でき る棲久分けがなされていることが明らかになった。

さらに低温環境に生息するビブリオ科細菌の多様性を 明らかにする目的で, 日本沿岸のさまざまな内湾からビ ブリオ科細菌を採集し，同様の方法でグルーピングを試 みたところ，V. splendidusに類似した菌株が優占し た。このV. splendidus の類似菌は, カナダやスペイン からも報告されて抢り, 9,10) 温帯以北で広範囲に生息し ていることが確認された。またこれらのV. splendidus に類似したすべての菌株は, RFLPで特徵的なパターン を示し，これまでに知られているどのビブリオ科の菌種 とも一致しなかった。以上の結果から，たとえ我々にと って身近な北部温帯域の沿岸環境で低温適応している菌 群の中にも，まだまだ知られていないものが多く含まれ

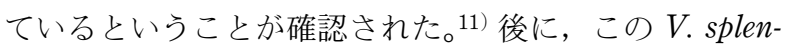
didusに類似した菌群が注目され, その多くが新種とし て提案されることとなった。12)

\section{2. 堆積物中の微生物群集に関する研究}

環境中に生息する多くの微生物は培養できない。13) そ こで堆積物試料から直接核酸を抽出し, 試料中の細菌群 集を解析する $16 \mathrm{~S}$ rRNA クローン解析手法の開発を行 った。微生物調査は東京湾と相模湾の堆積物コア試料に ついて行なった。この中で, 海洋堆積物中には Gammaproteobacteria が多く, 海水中や, 土畩に多い Alphaproteobacteria や, 淡水環境に多いBetaproteobacteria などが少ないことを明らかにしてきた。14) また $16 \mathrm{~S}$ rRNA クローン解析手法と比較してより効率的に多検体 を分析するのに適した, terminal restriction fragment length polymorphism (T-RFLP) 解析法を海洋堆積物の 微生物群集解析に利用した。これにより, 多検体の遺伝 子プロファイルの比較が容易になった。一連の研究の中 で, 海洋堆積物群集は, 鉛直方向に対する群集変化より も, むしろ水平的な群集変化のほうが大きいことや, 東 京湾では好気的な環境でも嫌気的な環境でも増殖可能な 通性嫌気性細菌が，堆積物中で優占する可能性について も明らかにしてきた。15)

また細菌の呼吸鎖の構成成分であるキノンを用いた分 析を, 遺伝子解析手法と組み合わせることにより, 研究 を行なった。15-17) $16 \mathrm{~S}$ rRNA 遺伝子の T-RFLP 解析で は強い類似性を示した相模湾の 2 地点からの試料と, 南海トラフ由来の試料が, キノン分析では明瞭に区別で きた。このことからも遺伝的に類似した深海底微生物群 集でも場所や深度が異なると, 呼吸鎖の違いや菌の生理 的状態に違いが見られることが示された。16)

東京湾に流れ込む処理排水中に含まれる硝化細菌が，
天然環境に与える影響を調査するために, 硝化細菌のひ とつであるアンモニア酸化細菌の研究を行なった。この 研究により, 堆積物中のアンモニア酸化細菌数は, 定量 PCR 法では堆積物中の全細菌数の $0.1-1.1 \%$, 蛍光抗体 法では 1.2-4.3\%に相当すると見積もられた。また優占 したアンモニア酸化細菌は, 下水処理場で優占する Nitrosomonas oligotropha とは異なり, Nitrosomonas sp. $\mathrm{Nm} 143$ というアンモニア酸化細菌のグループに属して いた。これまでこのアンモニア酸化細菌のグループは, 沿岸域からのみ発見されていることからも, 東京湾の堆 積物中に生息するアンモニア酸化細菌は処理水由来では なく, 海洋固有の細菌であることが示された。18)

\section{DNA マイクロアレイを用いた環境微生物研究}

DNA マイクロアレイ技術は, 表面を特殊加工したス ライドグラスなどの固相基盤上に, 数十から数万個の異 なる DNA プローブを高密度に配置し, 蛍光標識核酸を ハイブリダイズさせ, 各々の DNA プローブからのシグ ナルを蛍光イメージとして検出し, 統計的に解析するも のであり, 多数の遺伝子の挙動を網羅的に捉えることが 可能である。このDNA マイクロアレイは当初, 医学, 薬学, 分子生物学の研究分野に扔いて発達し, 現在では さまざまな分野に展開されている。環境微生物学の分野 に扔いても, rRNA を標的とした微生物の検出や同定, mRNA を標的とした微生物の遺伝子発現解析などの研 究に適用されている。19,20) しかしながら, DNA マイク ロアレイは発展途上の技術であり, クロスハイブリダイ ゼーションや検出感度, 定量性などの問題を抱えてい る。そのため, 現在でも多くの研究者がそれらの問題を 克服するために技術開発を行って抢り, 環境微生物学へ 適用した研究が少ないのが現状である。そこで, 幅広い 環境微生物の検出が可能な, rRNAを標的とした DNA マイクロアレイの開発を行ってきた。 DNA マイクロアレイが, 標的遺伝子の PCR 増幅を用 いることなく, 簡易迅速に環境中の微生物群集の動態を 明らかにする研究手法になり得ることを示してき た。23-25)

また硝化細菌のひとつであるNitrosomonas europaea の全ゲノム配列が明らかになったことを受け, ${ }^{26)}$ 全ゲノ ム遺伝情報をもとにした DNA マイクロアレイの作成が 可能になった。そこで mRNAを標的とした DNA マイ クロアレイによる直鎖アルキルベンゼンスルホン酸塩 （LAS）に対するアンモニア酸化細菌の遺伝子発現解析 を行ってきた。従来まで, アンモニア酸化細菌の LAS に対する感受性が，他の細菌と比較して高い理由につい ては謎とされてきた。しかし研究により, 膜に介在する アンモニア酸化に関わる酵素群が LAS に高い感受性を 示すことが mRNAの発現レベルで確認された。このよ 
うに，DNA マイクロアレイを用いることで，物質循環 や難分解性物質の分解にとって重要な微生物の遺伝子レ ベルでの研究を効率的に行うことが可能になってきた。

\section{4. 海洋微生物の分子生態学研究の将来像}

現在, 微生物ゲノムの遺伝情報を利用した研究が活発 に進みつつあり, 多くの知見が蓄積されつつある。今後 も海洋微生物学に導入された分子生物学的研究手法によ り, 海洋微生物にまつわる, さらなる発見が続くものと 予想される。

\section{謝辞}

本研究を行なうにあたり格段のご指導とご助言を賜つ た, 熊本県立大学環境共生学部 大和田紘一教授に深く 感謝を申し上げます。また，有用なご助言を賜った東京 大学海洋研究所 木暮一啓教授, 塚本久美子博士に深く 感謝を申し上げます。ビブリオ科細菌の研究を始めるき っかけを与えてくださった東北大学大学院農学研究科 室賀清邦教授, 広島大学大学院生物圏科学研究科 中井 敏博教授に感謝します。留学期間中には米国ワシントン 大学都市環境工学部 David A. Stahl 教授に大変多くの ことを教わりました。そして現在の研究を支えてくださ っている, 早稲田大学理工学部 常田聡助教授のご助力 に深く感謝を申し上げます。またこれまでの研究は，有 能な共同研究者や学生諸氏の多大なご協力から生まれた ものです。多くの方々のお力添えがありましたことをこ こに記し，皆様に心から扔礼申し上げます。

\section{文献}

1) DeLong EF, Karl DM. Genomic perspectives in microbial oceanography. Nature 2005; 437: 336-342.

2) Urakawa H, Kita-Tsukamoto K, Ohwada K. $16 \mathrm{~S}$ rDNA genotyping using PCR/RFLP (restriction fragment length polymorphism) analysis among the family Vibrionaceae. FEMS Microbiol. Lett. 1997; 152: 125-132.

3) Urakawa H, Kita-Tsukamoto K, Ohwada K. A new approach to separate the genus Photobacterium from Vibrio with RFLP patterns by HhaI digestion of PCR-amplified 16S rDNA. Curr. Microbiol. 1998; 36: 171-174.

4) Urakawa H, Kita-Tsukamoto K, Ohwada K. Reassessment of the taxonomic position of Vibrio iliopiscarius (Onarheim et al. 1994) and proposal for Photobacterium iliopiscarium comb. nov. Int. J. Syst. Bacteriol. 1999; 49: 257 -260 .

5) Colwell RR, Morita RY. Reisolation and emendation of description of Vibrio marinus (Russell) Ford. J. Bacteriol. 1964; 88: 831-837.

6) Morita RY. Psychrophilic bacteria. Bacteriol. Rev. 1975; 39: 144-167.

7) Urakawa H, Kita-Tsukamoto K, Ohwada K. Restriction fragment length polymorphism analysis of psychrophilic and psychrotrophic Vibrio and Photobacterium from the north-western Pacific Ocean and Otsuchi Bay, Japan. Can. J. Microbiol. 1999; 45: 67-76.
8) Urakawa H, Kita-Tsukamoto K, Steven SE, Ohwada K, Colwell RR. A proposal to transfer Vibrio marinus (Russell 1891) to a new genus Moritella gen. nov. as Moritella marina comb. nov. FEMS Microbiol. Lett. 1998; 165: 373378.

9) Martin-Kearley J, Gow JA. Numerical taxonomy of Vibrionaceae from Newfoundland coastal waters. Can. J. Microbiol. 1994; 40: 355-361.

10) Ortigosa M, Garay E, Pujalte M. Numerical taxonomy of Vibrionaceae isolated from oysters and seawater along an annual cycle. Syst. Appl. Microbiol. 1994; 17: 216-225.

11) Urakawa H, Rivera ING. Aquatic Environment. In: Thompson FL, Austin B, Swings J (eds). The Biology of Vibrios. ASM Press, Washington DC. 2006; 175-189.

12) Le-Roux F, Austin B. Vibrio splendidus. In: Thompson FL, Austin B, Swings J (eds). The Biology of Vibrios. ASM Press, Washington DC. 2006; 285-296.

13) Amann RI, Ludwig W, Schleifer K-H. Phylogenetic identification and in situ detection of individual microbial cells without cultivation. Microbiol. Rev. 1995; 59: 143-169.

14) Urakawa H, Kita-Tsukamoto K, Ohwada K. Microbial diversity in marine sediments from Sagami Bay and Tokyo Bay, Japan, as determined by $16 \mathrm{~S}$ rRNA gene analysis. Microbiology 1999; 145: 3305-3315.

15) Urakawa H, Yoshida $T$, Nishimura M, Ohwada $K$. Characterization of depth-related population variation in microbial communities of a coastal marine sediment using 16S rDNA-based approaches and quinone profiling. Environ. Microbiol. 2000; 2: 542-554.

16) Urakawa H, Yoshida $T$, Nishimura M, Ohwada K. Characterization of microbial communities in marine surface sediments by terminal-restriction fragment length polymorphism (T-RFLP) analysis and quinone profiling. Mar. Ecol. Prog. Ser. 2001; 220: 47-57.

17) Urakawa H, Yoshida T, Nishimura M, Ohwada K. Characterization of depth-related changes and sitespecific differences of microbial communities in marine sediments using quinone profiles. Fish. Sci. 2005; 71: 174182.

18) Urakawa H, Kurata S, Fujiwara T, Kuroiwa D, Maki H, Kawabata S, Hiwatari T. Ando H. Kawai T. Watanabe M, K. Kohata. Characterization and quantification of ammonia-oxidizing bacteria in eutrophic coastal marine sediments using polyphasic molecular approaches and immunofluorescence staining. Environ. Microbiol. 2006; 8: 787-803.

19) Zhou J. Microarrays for bacterial detection and microbial community analysis. Curr. Opin. Microbiol. 2003; 6: 288294.

20) Bodrossy L, Sessitsch A. Oligonucleotide microarrays in microbial diagnostics. Curr. Opin. Microbiol. 2004; 7: 245254.

21) Urakawa H, Noble PA, El Fantroussi S, Kelly JJ, Stahl DA. Single-base-pair discrimination of terminal mismatches by using oligonucleotide microarrays and neural network analyses. Appl. Environ. Microbiol. 2002; 68: 235 -244 .

22) Urakawa H, El Fantroussi S, Smidt H, Smoot JC, Tribou EH, Kelly JJ, Noble PA, Stahl DA. Optimization of singlebase-pair mismatch discrimination in oligonucleotide microarrays. Appl. Environ. Microbiol. 2003; 69: 28482856.

23) Koizumi Y, Kelly JJ, Nakagawa T, Urakawa H, El-Fan- 
troussi S, Al-Muzaini S, Fukui M, Urushigawa Y, Stahl DA. Parallel characterization of anaerobic toluene- and ethylbenzene-degrading microbial consortia by PCRdenaturing gradient gel electrophoresis, RNA-DNA membrane hybridization, and DNA microarray technology. Appl. Environ. Microbiol. 2002; 68: 3215-3225.

24) El Fantroussi S, Urakawa H, Bernhard AE, Kelly JJ, Noble PA, Smidt H, Yershov GM, Stahl DA. Direct profiling of environmental microbial populations by thermal dissociation analysis of native rRNAs hybridized to oligonucleotide microarrays. Appl. Environ. Microbiol. 2003; 69: 2377-2382.
25) Kelly JJ, Siripong S, McCormack J, Janus LR, Urakawa H, El Fantroussi S, Noble PA, Sappelsa L, Rittmann BE, Stahl DA. DNA microarray detection of nitrifying bacterial $16 \mathrm{~S}$ rRNA in wastewater treatment plant samples. Water Res. 2005; 39: 3229-3238.

26) Chain P, Lamerdin J, Larimer F, Regala W, Lao V, Land M, Hauser L, Hooper A, Klotz M, Norton J, SayavedraSoto L, Arciero D, Hommes N, Whittaker M, Arp D. Complete genome sequence of the ammonia-oxidizing bacterium and obligate chemolithoautotroph Nitrosomonas europaea. J. Bacteriol. 2003; 185: 2759-2773. 